\title{
ANALISIS HAMBATAN BELAJAR MAHASISWA PADA MATA KULIAH STRUKTUR ALJABAR II
}

Oleh

Diyah Hoiriyah $^{1}$

\begin{abstract}
The purpose of this study is to reveal the barriers to student learning in the Algebra Structure II course on Ring Material. The research subjects were students of the Tadris / Mathematics Education Study Program at the State Islamic Institute (IAIN) Padangsidimpuan in semester 6 as many as 5 students in the 2017-2018 academic year. Where in this study is a type of descriptive research using a qualitative approach. The data collection techniques are carried out, namely: documentation method, test method, and interview method. Data analysis was done by comparing the results of the Algebra Structure II test data and the results of interviews with students. The results of the analysis show that the obstacles to student learning in Algebra Structure II subjects are hampered by conceptual errors, are hampered by strategic errors, are hampered by calculation errors and are hampered by systematic errors. The alternative is to overcome these obstacles, it is necessary for lecturers to be able to develop a learning strategy in the form of giving a variety of problem exercises to students continuously especially those related to Ring material so that students can be more refined thinking skills.
\end{abstract}

\begin{abstract}
Abstrak
Tujuan penelitian ini untuk mengungkapkan hambatan belajar mahasiswa dalam mata kuliah Struktur Aljabar II pada Materi Ring. Subjek penelitian adalah mahasiswa Program Studi Tadris/Pendidikan Matematika Institut Agama Islam Negeri (IAIN) Padangsidimpuan semester VI sebanyak 5 mahasiswa pada tahun akademik 2017-2018. Dimana dalam penelitian ini merupakanan jenis penelitian diskriptif dengan menggunakan pendekatan kualitatif. Adapun teknik pengumpulan data yang dilakukan, yaitu: metode dokumentasi, metode tes, dan metode wawancara. Analisis data dilakukan dengan cara membandingkan data hasil tes Struktur Aljabar II dan data hasil wawancara dengan mahasiswa. Hasil analisis menunjukkan bahwa yang menjadi hambatan-hambatan mahasiswa dalam belajar pada mata
\end{abstract}


kuliah Struktur Aljabar II adalah terhambat karena kesalahan konsep, terhambat karena kesalahan strategi, terhambat karena kesalahan hitung dan terhambat karena kesalahan sistematik. Alternatif mengatasi hambatan-hambatan tersebut, perlu bagi dosen pengampuh mata kuliah stuktur aljabar II untuk dapat mengembangkan strategi pembelajarannya berupa memberikan latihan-latihan soal yang bervariasi kepada mahasiswa secara kontinu terutama yang brkaitan dengan materi Ring agar mahasiswa dapat lebih terasah kemampuan berfikirnya.

\section{Kata kunci: Hambatan Belajar, Struktur Aljabar II}

\section{PENDAHULUAN}

Belajar menurut Witherington adalah suatu perubahan di dalam kepribadian yang menyatakan diri sebagai suatu pola baru, pada ranah reaksi kecakapan, sikap, kebiasaan, atau suatu kepandaian. ${ }^{1}$ Sedangkan menurut Hamalik, belajar merupakan suatu proses perubahan tingkah laku individu melalui interaksi lingkungan. ${ }^{2}$ Sejalan dengan itu, Slameto mendefinisikan belajar sebagai suatu proses usaha yang dilakukan seseorang untuk memperoleh suatu perubahan tingkah laku yang baru secara keseluruhan, sebagai hasil pengalamannya sendiri dalam interaksi dalam lingkungannya. ${ }^{3}$ Dengan demikian belajar itu pada prinsipnya adalah perubahan, baik perubahan tingkah laku maupun perubahan akan bertambahnya pengetahuan pada individu-individu yang belajar.

Perubahan yang terjadi pada individu tersebut bersifat membekas dalam jangka waktu yang lama. Perubahan-perubahan itu tidak hanya berkaitan dengan penambahan ilmu pengetahuan, tetapi juga berbentuk kecakapan, keterampilan, sikap, pengertian, harga diri, minat, watak, penyesuaian diri dan dapat berupa halhal yang baru maupun penyempurnaan dari hasil yang diperoleh sebelumnya.

Pembelajaran erat kaitannya dengan belajar. Menurut Dimyanti dan Mudjiono, pembelajaran adalah kegiatan guru secara terprogram dalam desain intruksional, untuk membuat siswa belajarn secara aktif, yang menekankan pada

\footnotetext{
${ }^{1}$ Purwanto, Ngalim. 2010. Psikologi Pendidikan. Bandung: Remaja Rosdakarya. hal. 84

2 Oemar Hamalik. 2008. Proses Belajar Mengajar. Jakarta: Bumi Aksara. hal. 28.

3 Slameto. 2003. Belajar dan Faktor-faktor yang Mempengaruhinya. Jakarta: Rineka Cipta.
} hal. 2. 
penyediaan sumber belajar. ${ }^{4}$ Dengan demikian pembelajaran mengandung makna adanya kegiatan mengajar dan belajar, di mana pihak yang mengajar dalam penelitian ini adalah dosen yang dapat membangun dan mengembangkan aktivitas belajar mahasiswa serta dapat meningkatkan kemampuan mengkonstruksi pengetahuan baru sebagai upaya meningkatkan penguasaan yang baik terhadap materi pelajaran dan yang belajar adalah mahasiswa yang berorientasi pada kegiatan mengajarkan materi yang berorientasi pada pengembangan pengetahuan, sikap, dan keterampilan mahasiswa sebagai sasaran pembelajaran. Pada proses pembelajaran akan mencakup berbagai komponen lainnya, seperti media, kurikulum, dan fasilitas pembelajaran.

Mahasiswa secara alamiah mengalami situasi yang dinamakan hambatan belajar (learning obstacle). Adapun faktor penyebab hambatan belajar tersebut anatara lain adalah hambatan ontogeni (kesiapan mental belajar), didaktik (akibat pengajaran dosen), dan epistimologi (pengetahuan mahasiswa yang memiliki konteks aplikasi yang terbatas).

Selain dari hambatan-hambatan tersebut di atas, kesulitan belajar juga merupakan hambatan dalam belajar. Rumini dkk, mengemukakan bahwa kesulitan belajar merupakan kondisi saat peserta didik mengalami hambatanhambatan tertentu untuk mengikuti proses pembelajaran dan mencapai hasil belajar secara optimal. ${ }^{5}$ Menurut Blassic dan Jones, kesulitan belajar yang dialami siswa menunjukkan adanya kesenjangan atau jarak antara prestasi akademik yang diharapkan dengan prestasi akademik yang dicapai oleh peserta didik pada kenyataan (prestasi aktual). ${ }^{6}$ Dimana kesulitan tersebut merupakan hal-hal atau gangguan yang mengakibatkan kegagalan atau setidaknya menjadi gangguan yang dapat menghambat kemajuan belajar. Sehingga dapat disimpulkan bahwa kesulitan belajar itu merupakan hambatan yang dialami oleh mahasiswa dalam proses belajar yang menyebabkan mahasiswa mendapatkan hasil yang kurang optimal dalam proses belajarnya.

Kesulitan belajar yang merupakan hambatan belajar dalam penelitian ini adalah hambatan belajar mahasiswa pada mata kuliah Struktur Aljabar II. Struktur Aljabar II adalah mata kuliah lanjutan dari Struktur Aljabar I. Struktur Aljabar II merupakan mata kuliah yang wajib ditempuh oleh mahasiswa Program Studi 297.

4 Dimyanti dan Mudjiono. 2006. Belajar dan Pembelajaran. Jakarta: Rineka Cipta. hal.

${ }^{5}$ Irham, M \& Wiyani, A.N. 2013. Psikologi Pendidikan. Yogyakarta: Ar-Ruzz Media. hal. 254.

${ }^{6}$ Ibid.,hal. 253. 
Tadris/Pendidikan Matematika IAIN Padangsidimpuan yang membahas tentang Ring. Dimana materi Ring adalah lanjutan dari teori grup.

Sampai saat ini, Struktur Aljabar II masih merupakan matakuliah yang sulit bagi mahasiswa Program Studi Tadris/Pendidikan Matematika IAIN Padangsidimpuan, hal ini terlihat dari rendahnya nilai Struktur Aljabar II. Rendahnya nilai Struktur Aljabar II mahasiswa menunjukkan adanya masalah yang merupakan hambatan belajar mahasiswa. Berdasarkan hasil wawancara peneliti terhadap mahasiswa Program Studi Tadris/Pendidikan Matematika IAIN Padangsidimpuan semester VI tahun akademik 2017/2018 menyebutkan bahwa mahasiswa mengalami kesulitan saat mengerjakan soal-soal Struktur Aljabar II yang berkaitan dengan materi pada Struktur Aljabar I. Mahasiswa mengungkapkan bahwa dalam proses pembelajaran Struktur Aljabar II, mahasiswa mengalami kesulitan dalam pembuktian teorema, mengerjakan soal-soal, serta memahami konsep Struktur Ajabar dan ketelitian dalam menyelesaikan soal-soal secara sistematika aljabarnya. Dimana kesulitan-kesulitan yang diungkapkan mahasiswa tersebut dianggap sebagai hambatan dalam belajar mata kuliah Struktur Aljabar II.

Berdasarkan jabaran di atas, peneliti tertarik untuk menganalisis hambatanhambatan mahasiswa dalam belajar pada mata kuliah Struktur Aljabar II. Sehingga dengan dilakukannya analisis hambatan belajar ini dapat dijadikan acuan untuk menyusun perangkat pembelajaran yang terdiri dari silabus, lembar kerja mahasiswa, serta prediksi respon dan antisipasi didaktik. Dari hasil penelitian ini diharapkan dapat memberikan petunjuk dan solusi tentang hambatan belajar mahasiswa dalam memahami konsep Srtuktur Aljabar II serta sebagai penelitian pendahuluan dalam pengembangan bahan ajar Srtuktur Aljabar II.

\section{METODE PENELITIAN}

Penelitian dilakukan di Institut Agama Islam Negeri (IAIN) Padangsidimpuan, semester genap tahun 2017-2018. Subjek penelitian adalah mahasiswa Program Studi Tadris/Pendidikan Matematika Institut Agama Islam Negeri (IAIN) Padangsidimpuan semester VI sebanyak 5 mahasiswa. Pemilihan subjek penelitian ini berdasarkan teknik pengambilan purposive sampling. Purposive sampling merupakan suatu teknik penentuan sampel dengan pertimbangan tertentu. ${ }^{7}$ Adapun pertimbangan peneliti dalam penentuan subjek penelitian ini adalah berdasarkan hasil nilai Struktur Aljabar I mahasiswa.

7 Sugiyono. 2015. Metode Penelitian Pendidikan Pendekatan Kuantitatif, Kualitatif, dan $R \& D$. Bandung: Alfabeta. hal. 300 . 
Mahasiswa yang terpilih adalah mahasiswa yang memiliki nilai terendah pada Mata Kuliah Struktur Aljabar I.

Penelitian ini menggunakan pendekatan kualitatif dengan jenis penelitian diskriptif untuk mengetahui hambatan-hambatan belajar mahasiswa pada mata kuliah struktur aljabar II. Menurut Bogdan dan Guba, penelitian kualitatif (naturalistic inquiry) adalah prosedur penelitian yang menghasilkan data deskriptif berupa kata-kata tertulis atau lisan dari orang-orang dan perilaku yang dapat diamati. ${ }^{8}$ Sedangkan menurut Norman penelitian kualitatif merupakan fokus perhatian dengan beragam metode, yang mencakup pendekatan interpretatif dan naturalistik terhadap subjek kajiannya. ${ }^{9}$

Tujuan penelitian kualitatif pada umumnya mencakup informasi tentang fenomena utama yang dieksplorasi dalam penelitian, partisipan penelitian, dan lokasi penelitian. ${ }^{10}$ Penelitian kualitatif digunakan untuk mendapatkan analisis data yang mendalam dan bermakna.

Berdasarkan tujuan dari penelitian deskriptif kualitatif, maka peneliti bermaksud mendeskripsikan fenomena untuk mengungkapkan hambatan belajar mahasiswa dalam mata kuliah Struktur Aljabar II pada Materi Ring. Data mengenai hambatan belajar diperoleh melalui soal tes Struktur Aljabar II yang diberikan kepada mahasiswa. Adapun teknik pengumpulan data yang dilakukan, yaitu: metode dokumentasi, metode tes, dan metode wawancara. Instrumen pengumpulan data yang dipakai adalah instrument tes. Data yang diharapkan berupa hasil pekerjaan mahasiswa langsung pada lembar soal beserta langkahlangkahnya. Tujuan tes Struktur Aljabar II adalah untuk mengetahui kesulitan mahasiswa dalam menyelesaikan persoalan Struktur Aljabar II yang diinterprestasikan sebagai hambatan mahasiswa dalam belajar pada mata kuliah Struktur Aljabar II.

Wawancara dilaksanakan berdasarkan pedoman wawancara yang telah disusun. Data yang diperoleh berupa jawaban-jawaban subjek penelitian secara langsung mengenai tes Struktur Aljabar II. Jawaban-jawaban subjek penelitian berdasarkan wawancara digunakan sebagai triangulasi.

Adapun tahapan-tahapan dalam penelitian ini dalah sebagai berikut:

\footnotetext{
${ }^{8}$ Suharsaputra, U. 2012. Metode Penelitian Kuantitatif, Kualitatif, dan Tindakan. Bandung: Refika Aditama. Hal. 181.

${ }^{9}$ Patilima, H. 2013. Metode Penelitian Kualitatif. Bandung: Alfabeta. hal. 3.

${ }^{10}$ Creswell, John W. 2014. Research Design Pendekatan Kualitatif, Kuantitatif dan Mixed. Yogyakarta: Pustaka Pelajar. hal. 258.
} 
1. Peneliti mengadakan tes kemampuan awal (Materi Grup pada Mata Kuliah Struktur Aljabar I sebagai mata kuliah Prasyarat Struktur Aljabar II).

2. Peneliti dalam hal ini adalah dosen yang mengampuh mata kuliah Struktur Aljabar II mengadakan perkuliahan selama 8 kali tatap muka

3. Peneliti (dosen) mengadakan kuis dan penugasan.

4. Peneliti (dosen) mengadakan UTS.

\section{HASIL PENELITIAN DAN PEMBAHASAN}

Analisis hambatan merupakan suatu proses yang berdasarkan langkahlangkah berbeda, yakni untuk identifikasi, klarifikasi penjelasan, koreksi, penilaian, terapi dan pencegahan timbulnya kesalahan. Terjadinya kesalahan pada mahasiswa diantaranya dikarenakan oleh lemahnya kemampuan awal matematis dan miskonsepsi. Jadi terdapat beberapa tipe kesalahan yang cenderung dilakukan oleh mahasiswa yaitu kesalahan karena kecerobohan atau kurang cermat, kesalahan dalam keterampilan proses, kesalahan dalam memahami soal, kesalahan dalam transformasi, dan kesalahan dalam menggunakan notasi.

Beberapa contoh jawaban mahasiswa dalam mengerjakan soal Sruktur Aljabar II pada materi ring adalah sebagai berikut:

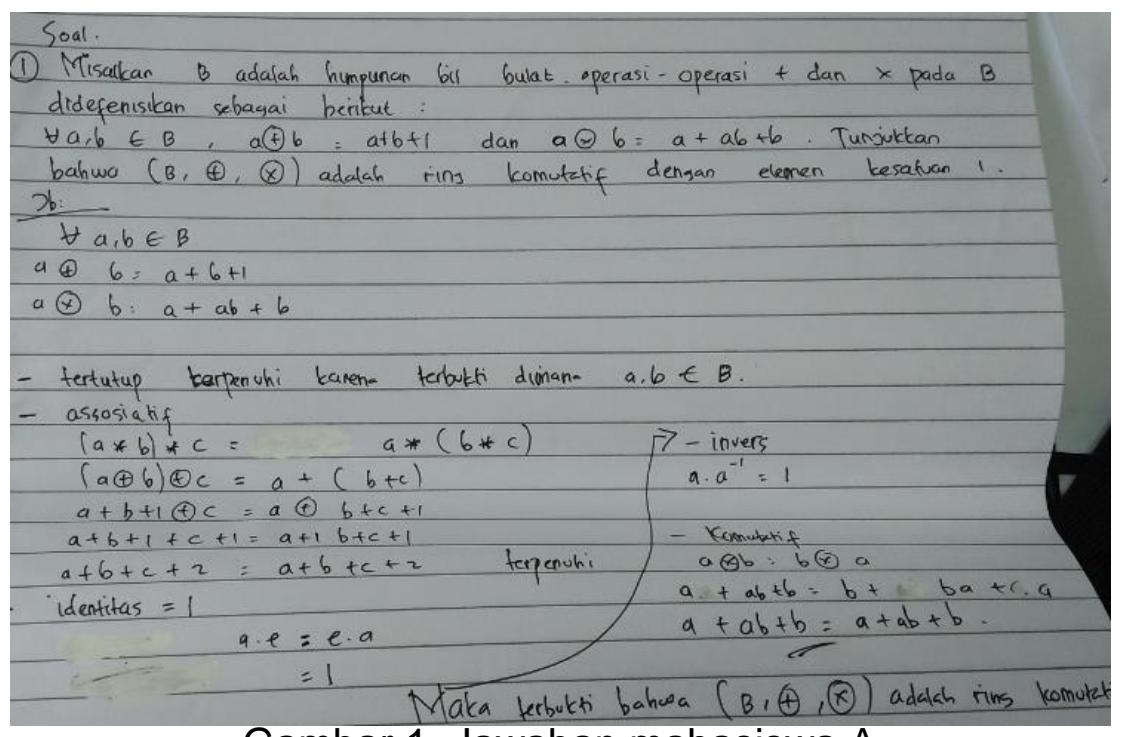

Gambar 1. Jawaban mahasiswa A 


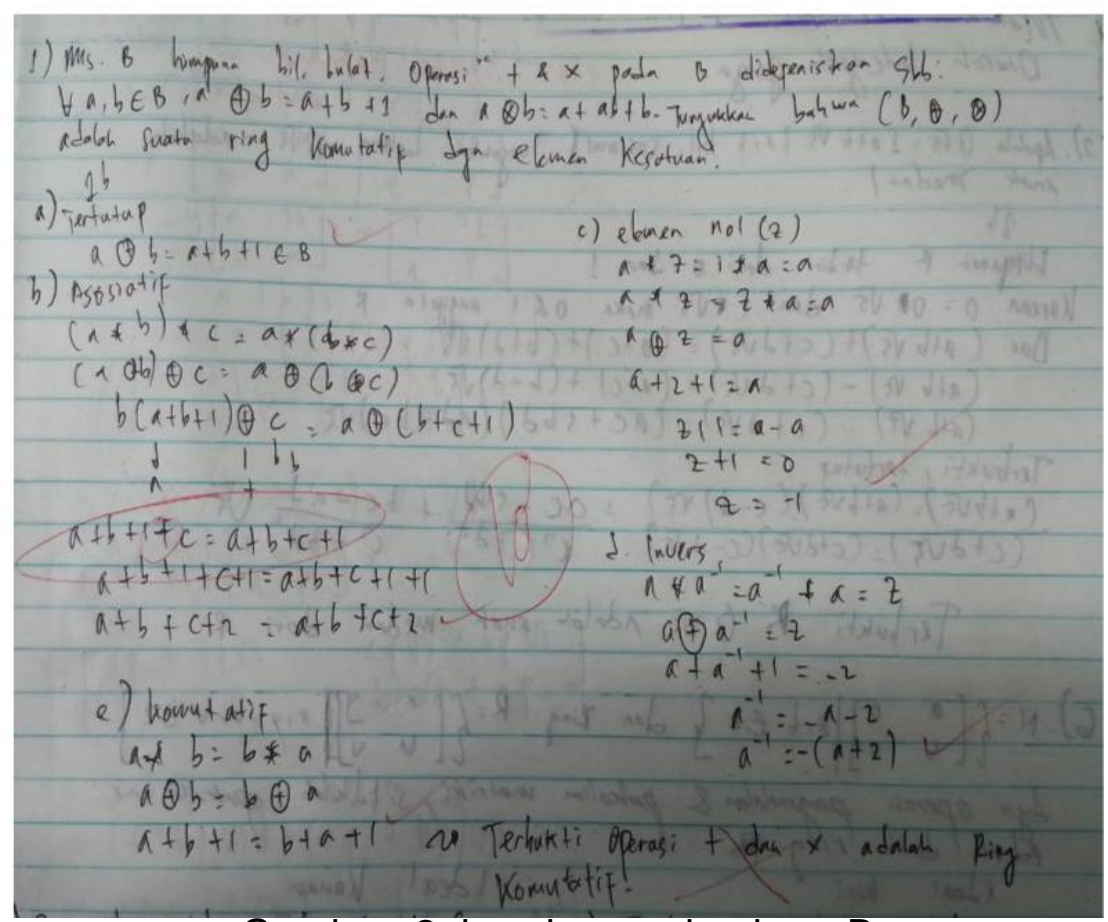

Gambar. 2: jawaban mahasiswa B

Pada jawaban di atas, mahasiswa cenderung langsung menyebutkan bahwa $(, \oplus, \odot)$ adalah ring komutatif. Dimana, pada jawaban mahasiswa A meyimpulkan $(\odot)$ adalah ring kumutatif karena telah membuktikan sifat komutatif pada operasi dua yaitu perkalian, tetapi mahásiswa tersebut lupa bahwa syarat dari ring komutatif bukan hanya membuktikan sifat komutatif pada operasi dua, tetapi juga harus membuktikan grurp abelian pada operasi pertama, semigrup pada operasi kedua, berlaku sifat distribusi dan berlaku sifat komutatif pada operasi kedua. Sedangkan pada jawaban mahasiswa $B$, meyimpulkan $(\oplus, \odot)$ adalah ring kumutatif hanya karena telah membuktikan sifat komutatif pada operasi pertama. Jelas bahwa kedua jawaban tersebut diatas, tidak membuktikan apa yang dikatakan dengan ring komutatif.

Dengan demikian, berdasarkan jawaban-jawaban mahasiswa di atas dapat analisis tentang hambatan belajar mahasiswa pada mata kuliah struktur aljabar II didapat fakta lapangan yaitu untuk tes diberikan kepada mahasiswa mengenai materi Ring. Analisis hasil tes Struktur Aljabar II adalah:

1. Pada saat membuktikan suatu soal tersebut adalah Ring atau bukan. Kesalahan mahasiswa antara lain tersebut adalah: a) kurang mampu mengingat/memahami definisi grup sebagai syarat dari ring, b) mahasiswa hanya menuliskan syarat grup pada operasi pertama ring, yang seharusnya grup abelian, c) kesalahan perhitungan atau kurang cermat dalam berhitung, d) kesalahan dalam menempatkan operasi pertama dan operasi kedua, e) 
kesalahan atau kurang hati-hati dalam menempatkan operasi (tidak memperhatikan operasi yang berlainan)

2. Pada saat membuktikan teorema pada ring. Kesalahan mahasiswa adalah: a) kurang mampu mengingat definisi grup, b) lupa teorema sebelumnya yang ada pada grup, c) lupa sifat-sifat ring

3. Pada saat membuktikan soal tersebut ring komutatif atau bukan. Kesalahan mahasiswa adalah cenderung menyebutkan suatu soal tersebut merupakan ring komutatif apabila berlaku sifat komutatif pada operasi pertama.

4. Pada saat menyelidiki soal tersebut merupakan ring dengan elemen kesatuan. Kesalahan mahasiswa adalah: a) cenderung menyebutkan suatu soal tersebut merupakan ring dengan elemen kesatuan apabila terdapat elemen identitas/ elemen nol pada operasi pertama, b) kurang mampu mengingat dan memahami istilah elemen nol dengan elemen kesatuan

Selain dari analisis tes struktur Aljabar II, peneliti juga melakukan wawancara terhadap mahasiswa. Adapun analisis dokumen hasil wawancara dengan mahasiswa adalah sebagi berikut:

1. Menurut mahasiswa pada saat menyelidiki apakah soal tersebut ring atau bukan, mahasiswa mengalami kesulitan dan tidak paham apa syarat suatu ring.

2. Menurut mahasiswa pada saat menyelidiki apakah soal tersebut ring atu bukan Mahasiswa mengalami kesulitan dalam prosedur perhitungan atau membuat tabel cayley pada himpunan berhingga, dikarenakan lupa apa yang dimaksud dengan modulo.

3. Untuk soal yang lebih abstrak, menurut mahasiswa pada saat menyelidiki apakah soal tersebut ring atau bukan, mahasiswa kesulitan dalam menafsirkan soal yang didefinisikan terhadap sifat-sifat ring.

4. Menurut mahasiswa pada saat menentukan apakah soal tersebut adalah ring komutatif atau bukan, kesulitan dalam menentukan pilihan karena sifat komutatif sudah terbukti pada operasi pertama ring, yaitu pada saat membuktikan sifat grup abelian.

5. Menurut mahasiswa pada saat menentukan apakah soal tersebut merupakan ring dengan eleman kesatuan, mahasiswa sulit menentukanya karena sudah memiliki identitas pada operasi pertama, saat membuktikan soal tersebut merupakan grup abelian.

Berdasarkan analisis tes Strukur Aljabar II dan wawancara peneliti dengan mahasiswa, maka yang menjadi hambatan-hambatan mahasiswa dalam belajar pada mata kuliah Struktur Aljabar II adalah sebagai berikut: 
1. Terhambat karena kesalahan konsep, yaitu kesalahan yang yang dilakukan mahasiswa karena tidak memahami konsep tersebut dengan baik (tidak memahami definisi Ring).

2. Terhambat karena kesalahan strategi, yaitu kesalahan yang terjadi karena mahasiswa memilih cara mengerjakan yang tidak tepat.

3. Terhambat karena kesalahan hitung, yaitu kesalahan dalam melakukan operasi matematika baik pada opesari pertama ataupun operasi kedua.

4. Terhambat karena kesalahan sistematik, yaitu kesalahan yang berkenaan dengan pemilihan yang salah atas teknik ekstrapolasi.

\section{PENUTUP}

Berdasarkan hasil penelitian dapan pembahasan di atas dapat disimpulkan bahwa yang menjadi hambatan-hambatan mahasiswa dalam belajar pada mata kuliah Struktur Aljabar II adalah sebagai berikut:

1. Terhambat karena kesalahan konsep,

2. Terhambat karena kesalahan strategi,

3. Terhambat karena kesalahan hitung,

4. Terhambat karena kesalahan sistematik.

Untuk meminimalisir hambatan-hambatan mahasiswa dalam belajar pada mata kuliah Struktur Aljabar II, maka saran yang dapat dikemukakan peneliti adalah sebagai berikut:

1. Bagi mahasiswa hendaknya dapat menerapkan proses belajar yang bermakna dalam merima materi atau konsep-konsep yang diberikan. Mahasiswa harus aktif dalam setiap kegiatan pembelajaran dan tidak hanya terpusat pada konsep yang diajarkan donsen tapi lebih jauh mampuh mengingat konsep yang diajarkan sebelumnya dan mampuh mengembangkannya.

2. Bagi para dosen, diharapkan agar dapat memberikan tugas dalam belajar berdasarkan kondisi terstruktur sedemikian rupa agar mahasiswa merasa memperoleh dukungan dan keuntungan dalam kapasitasnya untuk menyelesaikan masalah secara mandiri. Serta memberikan latihan-latihan soal yang bervariasi kepada mahasiswa secara kontinu terutama yang brkaitan dengan materi Ring. 


\section{DAFTAR PUSTAKA}

Creswell, John W. 2014. Research Design Pendekatan Kualitatif, Kuantitatif dan Mixed. Yogyakarta: Pustaka Pelajar.

Dimyanti dan Mudjiono. 2006. Belajar dan Pembelajaran. Jakarta: Rineka Cipta. Irham, M \& Wiyani, A.N. 2013. Psikologi Pendidikan. Yogyakarta: Ar-Ruzz Media. Oemar Hamalik. 2008. Proses Belajar Mengajar. Jakarta: Bumi Aksara.

Patilima, H. 2013. Metode Penelitian Kualitatif. Bandung: Alfabeta.

Purwanto, Ngalim. 2010. Psikologi Pendidikan. Bandung: Remaja Rosdakarya.

Slameto. 2003. Belajar dan Faktor-faktor yang Mempengaruhinya. Jakarta: Rineka Cipta.

Sugiyono. 2015. Metode Penelitian Pendidikan Pendekatan Kuantitatif, Kualitatif, dan R\&D. Bandung: Alfabeta.

Suharsaputra, U. 2012. Metode Penelitian Kuantitatif, Kualitatif, dan Tindakan. Bandung: Refika Aditama. 